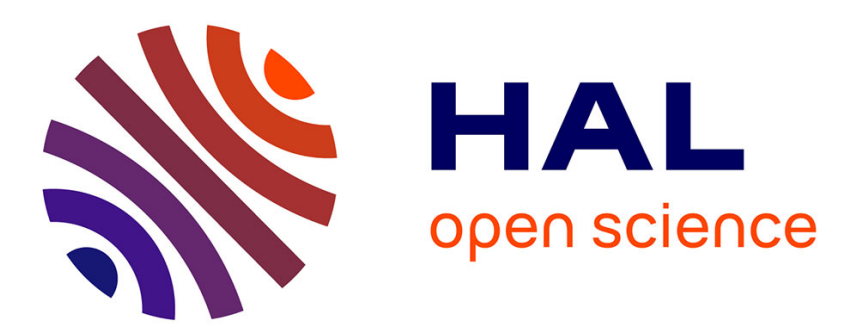

\title{
Profile of Building Information Modeling - BIM - Tools Maturity in Brazilian Civil Construction Scenery
}

Samuel Dos Santos, Oduvaldo Vendrametto, Miguel León González, Creusa Fernandes Correia

\section{- To cite this version:}

Samuel Dos Santos, Oduvaldo Vendrametto, Miguel León González, Creusa Fernandes Correia. Profile of Building Information Modeling - BIM - Tools Maturity in Brazilian Civil Construction Scenery. IFIP International Conference on Advances in Production Management Systems (APMS), Sep 2015, Tokyo, Japan. pp.291-298, 10.1007/978-3-319-22756-6_36 . hal-01417492

\author{
HAL Id: hal-01417492 \\ https://hal.science/hal-01417492
}

Submitted on 15 Dec 2016

HAL is a multi-disciplinary open access archive for the deposit and dissemination of scientific research documents, whether they are published or not. The documents may come from teaching and research institutions in France or abroad, or from public or private research centers.
L'archive ouverte pluridisciplinaire HAL, est destinée au dépôt et à la diffusion de documents scientifiques de niveau recherche, publiés ou non, émanant des établissements d'enseignement et de recherche français ou étrangers, des laboratoires publics ou privés.

\section{(c)(1)}

Distributed under a Creative Commons Attribution| 4.0 International License 


\title{
Profile of Building Information Modeling - BIM - Tools Maturity in Brazilian Civil Construction Scenery
}

\author{
Samuel Dereste dos Santos (samuel_dereste@yahoo.com.br) ${ }^{1,2}$, Oduvaldo \\ Vendrametto (oduvaldov@uol.com.br) ${ }^{1}$, Miguel León González \\ (miguel.leon@uol.com.br) ${ }^{2}$, Creusa Fernandes Correia ${ }^{2}$ \\ (creusa.profmategmail.com)
}

1 Paulista University-UNIP, Dr. Bacelar St. 1212, São Paulo, Brazil 2 Cruzeiro do Sul University-UNICSUL, Dr. Ussiel Cirillo Ave. 225, São Paulo, Brazil

\begin{abstract}
Building Information Modeling - BIM - tools are gaining, nowadays, great visibility by the possibility of integrated project development. The implementation of BIM tools is gaining space worldwide, including Brazilian scenery. Besides, the degree of tool implementation can vary depending the country, and can show how is the level of projects that are being developed. This paper evaluates the degree of BIM maturity implementation in Brazil's context, to find the differences of BIM software utilization under different projects. The strategy adopted was a technical review focused on periodical papers as well as a case study developed with 16 BIM expert's projects in Brazil. The results shown that Brazil presents an advanced BIM implementation considering BIS - Department of Business Innovations and Skills requirements, with great application in modeling, building installations, infrastructure, and low applicability on development of integrated projects.
\end{abstract}

Keywords: BIM, CAD, Profile, Maturity

\section{Introduction}

Building Information Modelling (BIM) has different definitions, with wide aspects considered by experts. It can be defined as the process of generating, storing, managing, exchanging, and sharing information from building process, in an interoperable and reusable way, with the use of a computer generated model to simulate the planning, design, construction and operational phases of a project [1]. The BIM - Building Information Modeling - tools are gaining, worldwide, great importance despite all this qualities for project development in AEC - Architecture, Engineering and Construction Area. This tool has conceptual differences when compared with other software and permits a project development more efficient [2].

An analysis of the project development history since 1950 shows that the advent of CAD - Computer Aided Design - tools remains the transfer to the computer information that was handmade manipulated. Besides, with software and computer popularization starts a process of evolution that changed the type of information manipulated.

adfa, p. 1, 2011 .

(C) Springer-Verlag Berlin Heidelberg 2011 
Besides all work integration possibilities of BIM tools nowadays, the construction industry worldwide still exhibits a low maturity in BIM use, since no significant changes in the traditional business model accompany the introduction of new tools [2]. The purpose of this study was to evaluate the degree of BIM maturity implementation in Brazil's context, to find the differences of BIM software utilization under different projects. The strategy was based on a technical review focused on periodical papers as well as a study developed with 16 BIM expert's projects in Brazil.

This paper is organized into sections as follows: introduction, technical review, case study, discussion and, finally, results and references.

\section{2 - Technical review}

\subsection{General Definition}

The Building Information Modelling (BIM) can be understood like an IT approach that involves applying and maintaining an integral digital representation of the building information, considering different phases of the project lifecycle, working like a data repository. The common data changed in this environment is geometric data, non-geometric data (parameters), and this information is joined in a virtual reality ambience, that allows research, collaboration, improve data integrity, intelligent documentation, retrieving of building data. All these characteristics allow a high quality process project, thorough an enhanced performance analysis, as well as multidisciplinary planning, verification and coordination [3]

This project model allows reducing design mistakes and increases productivity of construction industry because is being used not only one software, but a family of tools that, in an integrated way, results in an integrated model that have, inside, all the different projects steps and the different types of information joined in the same model. Such, BIM provides an emerging new paradigm for project development and construction management to architecture, engineering and construction industry [4].

The potential of productivity increased by BIM implementation express one consider modification in civil construction production projects. Besides the BIM definition, the need and possibility of project development in integrated and interoperable platforms was yet recognized already in the 1970s. BIM systems can be seen as an evolution of CAD systems through intelligence and interoperable increasing information [4].

When a business implement BIM solutions, there are a substantial impact through all stages of project and construction process. There is an expand of stakeholder collaboration through different steps of project development. However, is necessary a change in business processes, and not only a simple promotion technology. BIM implementation can affect all the processes, and cannot be treated only as a software change [1]. 
At final, with BIM implementation, is possible to have a more accurate way of working, as a reduction of waste/loses (materials, resources, hour-work, etc). Besides, the 3 dimensional work allows the development of a better project. Instead, it needs the generation of models in extranet/internet, what makes necessary the utilization of security protocols for information management [1].

\subsection{BIM Maturity}

The BIM implementation will not occur at the same way in all kind of business. BIM adopters will need to go through a managed process of changing, starting with the internal organization through external suppliers and clients. BIS - Department of Business Innovations and Skills - UK, developed a maturity model defining the levels from 0 through 3 (fig. 1) to understand software implementation in construction industry. Worldwide, great part of the market is still working with Level 1 processes, and the best in class are experiencing significant benefits in Level 2 [2].

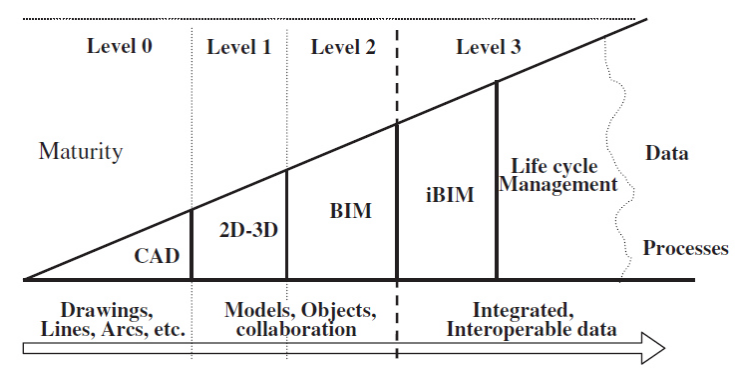

Fig. 1. - BIM maturity implementation [2]

According BIS, the BIM evolution can be divided into 4 levels. The level 0 consists in the first CAD applications for project development worldwide. The focus of these applications was bi-dimensional objects, and remains the transfer of handmade projects to computer in all areas, like aeronautics, mechanical and civil construction. The level 1 consists in the first efforts of make bi and tri-dimensional integrated objects, but the objects of this level are difficult to be integrated because they are still vectorized, like CAD previous tools [2].

In the sequence, the level 2 consists in the utilization of BIM first applications. However, the utilization in this phase are still modelling, without integration. At last, the level 3 consists in the application of BIM in an integrated manner, with the project development with different tools.

Others models were developed to understand the BIM implementation. Model Progression Specifications for BIM has been adopted by the American Institute of Architects to address the phase outcomes, milestones, and deliverables, and the idea of assigning tasks on a best person basis. The core was the level of detailing, which describes the steps of the BIM element logical progress. The levels of details ranged from the lowest level (100) of conceptual approximation to the highest level of representational precision (500) (fig. 2.) [2]. 


\begin{tabular}{|c|c|c|c|c|c|}
\hline \multicolumn{6}{|c|}{ Model Progression Specifications (AIA)* } \\
\hline Level of Detail & 100 & 200 & 300 & 400 & 500 \\
\hline Model Content & Conceptual & Approximate geometry & Precise geometry & Fabrication & As-Built \\
\hline \multirow[t]{5}{*}{ Design and Cordination } & Non-geometric data or line & Generic elements shown in & Confirmed 3D & Shop drawing/fabrication & \\
\hline & work, areas, volumes, & three dimensions & object geometry & - purchase & \\
\hline & zones etc. & - maximum size & - dimension & - manufacture & \\
\hline & & - purpose & - capacities & - install & \\
\hline & & & - connections & - specified & \\
\hline
\end{tabular}

Fig. 2. - Model Progress Specifications. Adapted from [2]

\subsection{BIM Implementation Stages and Definitions}

The evolution of BIM tools can be linked with the type of information manipulated in that phase. According [5], it can be defined by:

Table 1. - BIM stages and definitions. Adapted from [5].

\begin{tabular}{cl}
\hline Stage & \multicolumn{1}{c}{ Definition } \\
\hline 2D & $\begin{array}{l}\text { First CAD applications drawings. Use of lines, arcs, and geometric } \\
\text { vectors. }\end{array}$ \\
\hline 3D & $\begin{array}{l}\text { First tri-dimensional objects, with some parameters like construction } \\
\text { materials. }\end{array}$ \\
\hline 4D & $\begin{array}{l}\text { Models with time-production information. Possibility of production } \\
\text { planning using just-in-time solutions. }\end{array}$ \\
\hline 5D & $\begin{array}{l}\text { Models with cost-estimation. Each element of the building model has } \\
\text { a cost associated with it. It's allows for detailed analysis to be done } \\
\text { regarding budgets. }\end{array}$ \\
\hline 6D & $\begin{array}{l}\text { Sustainability analysis variables of building projects. LEED - Leader- } \\
\text { ship in Energy and Environmental Design - performance. }\end{array}$ \\
\hline 7D & $\begin{array}{l}\text { As-Built. Fundamental part to accurate Facilities Management. } \\
\text { Maintenance planning. }\end{array}$ \\
\hline
\end{tabular}

The BIM implementation in industry requires the adjustment of variables of working (cooperation between pairs, suppliers), hardware, operators (designers, engineers, architects, collaborators) and client demands. Worldwide, it had not a uniform implementation, where different solutions divide same partners, and it is a great challenge for BIM implementation. To understand these variables in Brazilian Civil Construction scenery, is necessary evaluate the market behavior. 


\section{Case Study}

\subsection{Description}

To understand the degree of BIM maturity implementation in Brazil, there was made an analysis of works presented by BIM experts of Brazil at "Autodesk University Brazil" in the years 2013 and 2014. In this event, the most important offices shows their BIM experiences developed in Brazil, what made the event one thermometer of how the companies are leading with this technology, and how is the level of BIM software integration in the country.

\subsection{Sampling}

Sixteen companies was analyzed by their case studies showed on lectures. There was $6.25 \%$ of small companies, $56.25 \%$ of medium companies and $37.5 \%$ of large companies. The business line of the companies were: $37.5 \%$ of companies develop architecture projects and infrastructure works, $18.75 \%$ of the companies works with control and planning production, and $6.25 \%$ with Building Systems (HVAC).

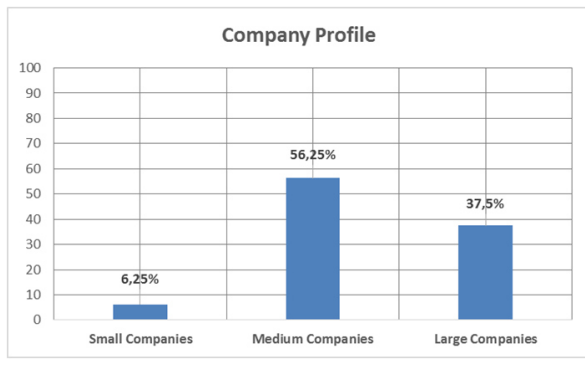

Fig. 3. - Company Profile

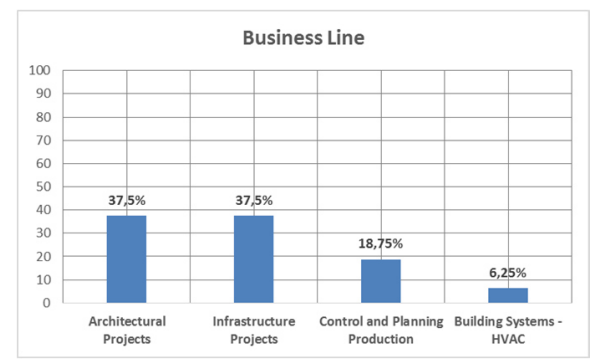

Fig. 4 - Business Line

\section{3 - BIS Data analysis and classification}

Second [2], the BIS made one classification based on levels to define de degree of maturity of BIM tools implementation. The BIS classification consider the scale showed at table 2. Analyzing the projects and materials available by enterprises, no ones were classified in Levels 0 and 1. About level 2,37.5\% of the companies were classified in this level because they are using BIM solutions only for modeling, without integration between different instances. So $62.5 \%$ were classified in Level 3 because they were using BIM solutions in a superior instance. 
Table 2. Level Definitions by BIS [2]

\begin{tabular}{|c|c|c|}
\hline Level & $\begin{array}{c}\text { Data } \\
\text { Information }\end{array}$ & Characteristics \\
\hline 0 & CAD & $\begin{array}{c}\text { Bi-dimensional in- } \\
\text { formation. Vector }\end{array}$ \\
\hline 1 & 2D-3D & $\begin{array}{c}\text { Tri-dimensional } \\
\text { information }\end{array}$ \\
\hline 2 & BIM & Parametric Objects \\
\hline 3 & $\begin{array}{c}\text { IBIM/Lifecyc } \\
\text { le Manage- } \\
\text { ment }\end{array}$ & $\begin{array}{c}\text { Parametric Objects. } \\
\text { Integrated Data. In- } \\
\text { teroperability }\end{array}$ \\
\hline
\end{tabular}

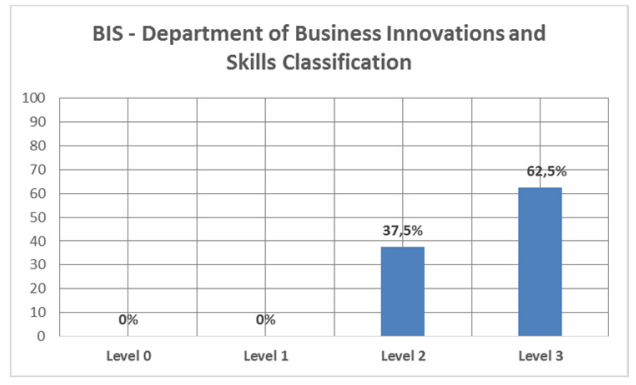

Fig. 5. BIS Classification Results

A problem resultant of this classification is the generalization made by BIS of how kind of works are being developed inside Level 3, that consider advanced one enterprise that develop projects at high BIM instances.

\section{4 - Category Data Analysis}

To resolve this problem, there was made another analysis dividing the BIM implementation into seven categories, named CAT-01, CAT-02, CAT-03, CAT-04, CAT-05, CAT-06 e CAT-07. The characteristic of each one are listed at table 3 . The objective was understand the differences between BIM implementations in the different enterprises, to know the particularities of each one.

Table 3. - Category BIM classification

\begin{tabular}{|c|c|c|}
\hline Category & $\begin{array}{c}\text { Data } \\
\text { Infor- } \\
\text { mation }\end{array}$ & Characteristics \\
\hline CAT-0 & 2D & $\begin{array}{c}\text { Bi-dimensional in- } \\
\text { formation }\end{array}$ \\
\hline CAT-1 & 3D & $\begin{array}{c}\text { Tri-dimensional in- } \\
\text { formation }\end{array}$ \\
\hline CAT-2 & BIM & $\begin{array}{c}\text { BIM for architec- } \\
\text { tural Modeling }\end{array}$ \\
\hline CAT-3 & i-BIM & Structural Analysis \\
\hline CAT-4 & i-BIM & $\begin{array}{c}\text { Building Systems / } \\
\text { HVAC }\end{array}$ \\
\hline CAT-5 & i-BIM & $\begin{array}{c}\text { Thermal and acous- } \\
\text { tic analysis }\end{array}$ \\
\hline CAT-6 & i-BIM & $\begin{array}{c}\text { Infrastructure Pro- } \\
\text { jects }\end{array}$ \\
\hline CAT-7 & i-BIM & $\begin{array}{c}\text { BIM Integration / } \\
\text { Interoperability }\end{array}$ \\
\hline
\end{tabular}

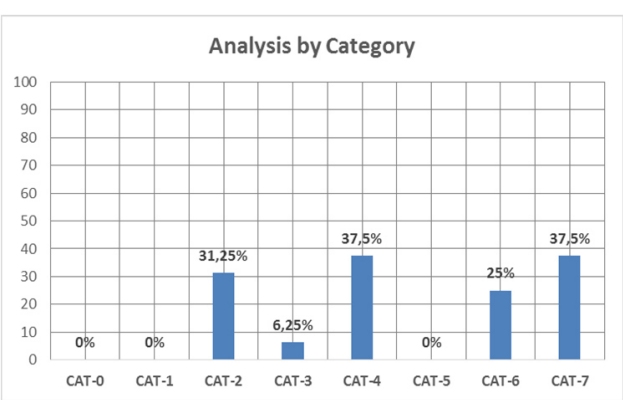

Fig. 6. Category Classification Results 


\section{Discussion}

The BIM implementation inside a company can get different results depending of the context. BIS classification can indicate the degree of BIM evolution inside a company. The results, according this classification, demonstrated that no enterprises are Level 0 or Level 1, and 37,5\% are Level 2 and 62,5\% are Level 3. These results indicates that great part of companies are implementing BIM tools into an advanced way.

However, the data analysis of Category Classification could shows that no enterprises are using only 2D and 3D solutions, but BIM for modeling $(31,25 \%)$, BIM for Structural Analysis (6,25\%), Building Systems (37,5\%) and Infrastructure Projects $(25 \%)$. No enterprises are using BIM for thermal and acoustic projects evaluation.

Another important aspect is the low rate of enterprises $(37,5 \%)$ using BIM in an integrated way. The great BIM challenge is the possibility of project development in a collaborative job. If the offices in Brazil are not implementing software integration in large scale, the BIM systems values are not full and contributes to a low evolution of the tool in the country.

\section{Conclusions}

BIM tools were a great change on project development. The study shown that, besides difficulties, the companies are implementing the tool. Considering the BIS classification, the companies are using the BIM tools into an advanced way, signaling that software implementation is accompanying the world context.

Besides, the Category Analysis showed a low application of structural analysis with BIM tools $(6,25 \%)$, and a great force in Modeling $(31,25 \%)$, HVAC $(37,5 \%)$ and Infrastructure $(25 \%)$. The Category Analysis also showed that great part of the companies $(62,5 \%)$ use BIM tools without instances integration. Companies did not mention the thermal and acoustic analysis.

To professionals, the BIM implementation in AEC industry means a better kind of tool for project development, with could permit the collaborative work, with is very interesting in our actual scenery, where the deadlines are short and changes need to be done in a fastest way. A collaborative work also permits project development without disciplines incompatibilities, contributing for a more efficiency project.

Besides, for Building and Facilities Managers, the growing of projects developed with BIM tools creates an opportunity for a better work, where all information is joined at same model, allowing a better maintenance of all building systems, saving energy and water, becoming ecological the building lifecycle.

The challenges of BIM implementation in Brazil are many, and, the BIM integration with interoperability data can be, in the long run, a way of better project development processes in Brazil context. 


\section{Acknowledgment}

The authors would like to thank CAPES (Coordenação de aperfeiçoamento de pessoal de nível superior) and Paulista University (UNIP) for the financial support to develop this work.

\section{$7 \quad$ References}

1. EARDIE, R. ; BROWNE, R. ; ODEYINKA, H. ; MCKEOWN, C. ; MACNIFF, S. BIM Implementation throughout the UK construction project lifecycle: an analysis in Automation in Construction, n.36, p. 145-151. Published online doi:10.1016/j.autcon.2013.09.001 (December 2013) (accessed on: March 2015)

2. PORWAL, A.; HEWAGE, K. N., Building Information Modeling (BIM) partnering framework for public construction projects in Automation in Construction, n.31, p. 203-214. Published online http://dx.doi.org/10.1016/j.autcon.2012.12.004 (May 2013) (accessed on: March 2014)

3. GU, N.; LONDON, K. Understanding and facilitating BIM adoption in the AEC industry in Automation in Construction, n. 19, p. 988-999. Published online http://doi:10.1016/j.autcon.2010.09.002 (December 2010) (accessed on: March 2014)

4. MIETTINEN, R.; PAAVOLA, S. Beyond the BIM Utopia: Approaches to the development and implementation of Building Information Modeling in Automation in Construction, $\mathrm{n}$. 43, p. 84-91. Published online http://doi:10.1016/j.autcon.2014.03.009 (July 2014) (accessed on: March 2014)

5. CALVERT, Neil. Why we care about BIM. Available at http://spatialiq.co.nz/index.php/uncategorized/why-we-care-about-bim/ . Acessed on March 2015. 